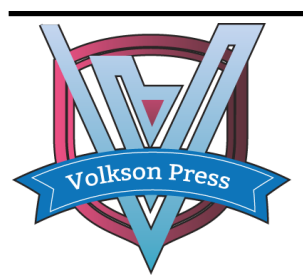

Contents List available at VOLKSON PRESS

Education, Culture and Social Development (ECSD)

DOI : http://doi.org/10.26480/icecsd.01.2018.90.97

Journal Homepage: : https://topicsonsocialdevelop.com/

\title{
EMBRACEMENT OF PHILOSOPHY OF LIFE AND INTUITIONISM IDEAS BY RUSSIAN LITERATURE
}

\author{
Ulbolsyn Abisheva1, Lyudmila Safronova ${ }^{2}$ \\ ${ }^{1}$ Department of Philology and World Languages, Al-Farabi Kazakh National University 71 Al-Farabi Ave., Almaty, Kazakhstan. \\ ${ }^{2}$ Institute of Philology and multilingual education, Kazakh National Pedagogic Abai University, 13, Dostyk Ave., Almaty, Kazakhstan. \\ *Corresponding author email: Abisheva.O.K@gmail.com, dinass2002@mail.ru
}

This is an open access article distributed under the Creative Commons Attribution License, which permits unrestricted use, distribution, and reproduction in any medium, provided the original work is properly cited

\section{ARTICLE DETAILS}

\section{Article History:}

Received 12 November 2017 Accepted 12 December 2017 Available online 1 January 2018

\section{ABSTRACT}

Philosophic and aesthetic origins of the early XX century Russian realism are discussed in the article. Significant changes took place in early XX century Russian prose that literary critic named it the Russian Literature Neorealism. This literary phenomenon is associated with such novelists as I. Bunin, B. Zaitsev, I. Shmelev, M. Prishvin, S. SergeyevZennskiy, A. Tolstoy and others who entered the stage at the end of XIX - beginning of XX centuries. Russian Neorealism, as a literary phenomenon, came to rise under complex evolutionary processes of artistic concepts. Its formation and aesthetic consolidation happened during the crisis of positivism. The theories of positivism dominated the Russian belle-lettre during 1880th and in its Narodnism movement. The latter was based on social determination of an individual and it interpreted the world through the prism of its social history. The crisis revealed that Positivism and Narodnism ideas had become outdated and unfit in the new, XXth, century.

Works by such representatives of Lebensphilosophie as W. Diltey, H. Bergson, F. Nietzsche, H. Rickert, O. Spengler, H. Simmel and those of the philosophical school of Intuitionism were especially popular in Russia at the turn of XX century. Literature of Russian Neorealism of early XX century was greatly influenced by these philosophers. Mutually enriching each other, the major ideas of Lebensphilosophie and Intuitionism philosophers shaped the world vision of the new generation of Russian writers who accepted the new values and shifted the accent on new concepts of Life and Individual. Philosophical ideas of these schools of thought aimed mostly at the theories of positivism and classical rationalism that held philosophical and scientific reasoning of their times. The impact of their philosophical ideas on rationalism caused denial of positivistic reasoning and that of social determinism of an individual so typical for the late stages of Narodnism literature.

\begin{abstract}
Theoretical reflections of Lebensphilosophie and Intuitivism about Life as a whole, full of vigorous though surreptitious and intense energy, had fueled a new artistic movement. Life could not be comprehended only rationally disputed philosophers of these schools of thought. Under their influence, the literature of Russian Neorealism rose to the new level of ideas about Life, its meaning and its complexity. In Russian Neorealism, the Concept of Being is based on awareness of the complex ever-changing rich world and on the idea that each and every phenomenon is connected with the infinite Universe. Novelism of writers of the Russian Neorealism movement is characterized by selfconcentration, self-confession, emotional and dramatic lyrism, acute sense of life impermanence and attempts to fill it in with personal, even intimate, content.
\end{abstract}

\section{KEYWORDS}

Russian Literature Neorealism, Lebensphilosophie, Philisophy of Life, Phylosophy of Intuitionism, metatext

\section{INTRODUCTION}

The period of $1900-1910^{\text {th }}$ is specified by rise of the so called Russian Neorealism as an aesthetic movement in Russian literature. The names of I.Bunin, B.Zaitsev, I.Shmelev, M.Prishvin, S. Sergeyev-Zennskiy, Ye. Zamyatin, A. Tolstoy and others are linked with this literary phenomenon due to their association named Publishing House of Moscow Novelists. The association did not have a distinct artistic stance in the form of a joint declaration, nor they had literary critics as Symbolism, Acmeism, and Futurism movements who artistically created and contemplated on the theoretical basis for their literary objectives and standpoints. However, lack of theoretical basis for their creed and goals did not mean lack of shared worldview. The novelists promoted the principles of renewed vision of realism via Slovo, a regularly published miscellany that reflected their aspiration to eternal values of life.

Russian realism at the turn of XX century was characterized by a dialectic approach to life, a broader interpretation of an individual, the world and the role of history in a human life. V.B. Katayev wrote that the Russian culture denied speculations about the death of realism during the transiting years between two centuries as well as through the entire XX century. The best oeuvres of Russian realism displayed its ability to draw into its orbit new phenomenae, to reveal new aesthetic opportunities as a self-sustained type of creativity and artistic contemplation about reality. The artistic literary movement that we call realism (admitting that the term is controversial) had a great re-generating potential obvious during that transitional period of the Russian culture [1].

Regeneration of realism had been prepared by the previous generation novelists: A. Chekhov, V. Garshin, V. Korolenko. The new times set new requirements for the new crop of novelists who felt a need to renew bellelettre. In 1900-1910 not only aesthetic and social viewpoints of writers caused the rise of neorealism movement in Russian literature but also the inherent logic of realism itself and its close interaction with modernism trends in Arts. L.A. Kolobayeva writes "Interaction of Russian Literature realism (in the broad sense of the term that comprised not only the XX 
century literature but its earlier periods as well) and Modernism was not only through their competition but also through interinfluence, repulsion and gravitation, infusion and mutual profiteering that became the driving force for Russian literature during the Silver Age" [2]. The Russian literature neorealism had broadened the realms of realism in the beginning of XX century. The philosophical and artistic features of Russian neorealism are characterized as a dynamic artistic technique open for exploration and evolution.

\subsection{History of the Issue and Research Techniques}

In this article we study the philosophical context, the metatext structure, regularities of plot and composition, key topics, and the reasons those topics were chosen by the Russian neorealism novelists B.Zaitsev, I. Bunin, and I. Shmelev. We are interested in crossings of different facets of Russian realism that renewed itself at the turn of XX century through works of these different in idiom authors.

We shall apply the method of typological comparison that allows to:

- reveal both general and underlying tendencies of the literary process;

- follow the direction of their shared world views;

- learn the common grounds for their philosophical searching; and

- find parallels in writers' topics and poetic styles.

Literary critics of the early XX century had an increased interest in qualitative transformations of Russian realism during 1900-1910 th that was named the Russian Literature neorealism. The term neorealism was coined and used in parallel with such terms as Synthetic Realism, New Realism, Spiritual Realism, Symbolic Realism in an attempt to distinguish the new realism from the classical realism. In popular Russian periodicals of that time, for example, Herald of Europe [Vestnik Evropy], Russian Thought [Russkaya Mysl], Contemporary World [Sovremenny Mir], Education [Obrazovanie], Legacy [Zavety] there were articles, book reviews, and digests focused on the new tendencies of Russian Literature. The aesthetic phenomenon of $1900-1910^{\text {th }}$ literature caught the attention of such leading literary critics as Yu. Aikhenvald, E. Koltonovskaya, P. Kogan, N. Korobka, R. Ivanov-Razumnik, etc., who shared fresh ideas about evolution of Realism. Usually, their articles were not crispy theoretical but dealing with day-to-day literary issues and following new publications. These and other literary critics specified significant features of the new realism and interpreted their vision of the tendency in terms of existing terminology and methodology.

The rise of Russian literature neorealism attracted the attention of literary critics already in 1900-1910. Many of them linked the creative future of Russian literature with new realism (see the most prominent analytical studies of the trend by Yu. Aikhenvald, R. Ivanov-Razumnik, A. Gornfeld, A. Toporkov, and, especially, E. Koltonovskaya. At that time the general idea was that the realism and symbolism movements did not develop independently but, sharing the same basis, they jointly searched for synthesis on different levels of a novel - the plot, composition, structure, poetics, and so on. Critic analysis was incorporated into reviews and comments of the ongoing literary process and had not mellowed to a fullfledged literary critic articles yet. It was the second half of XX century when the process continued considering the specificity of time and place, though the formal viewpoint of the Soviet philology refused to acknowledge bonds of the Russian Literature realism with the modernism movement and aesthetic interaction between them. Literary critics of 1950-1960 either silenced the topic or opposed the movements to each other insisting on their animosity. Simplification, schematism of the approach to the history of realism evolution would be overcome much later by Russian literary critics.

Russian Realism of early XX Century by V.A. Keldysh was published in 1975 and became the first specialized study of its kind. It provides the profound conceptual analysis of the general regularities and dynamics of the Russian literature realism as well as the rationalized concept of its evolution. Later on, in his literary critic written around year 2000, V.A. Keldysh was back into specifics of his 1975 interpretation of the topic. Specifically, he no longer viewed neorealism as a fringe trend. In 2001
V.A. Keldysh wrote that the Russian literature neorealism was a distinct movement within realism and it was more in contact with the ongoing modernism movement than any other movement of the time. He also wrote that the Russian Literature neorealism had been freed from the earlier powerful influence of naturalism [3].

There are certain achievements in studying the Russian Literature neorealism; however, no studies of its philosophic roots have been made so far. The study of the Russian Literature neorealism and, in general, Russian Literature realism at the turn of XX century has been complicated by lack of a developed theoretical basis. According to V.A. Keldysh, it did not have an aesthetic concept in any completed form compared to modernism and, specifically, symbolism that were in proactive pursuit of the philosophic and aesthetic provisions for their artistic legacies.

At the end of the XIX ${ }^{\text {th }}$ - beginning of XX $X^{\text {th }}$ centuries the theoretical platform of the Russian Literature realism significantly lagged behind the artistic movement [3]. The fact that each novelist of the neorealism movement had his own unique way of expression and artistic disposition does not help to study the topic either; however, the differences could not obscure the common ground provided by the philosophic context.

\section{MAIN TEXT}

\subsection{Re-invention of Life in European Philosophy}

Lebensphilosophie is a European philosophy school of thought at the last quarter of XIXth century. Prominent philosophers of that time - W. Diltey, H. Bergson, F. Nietzsche, H. Rickert, O. Spengler, H. Simmel and others were the founders and the think tank of it. Philosophy of Life was a very diverse movement characterized by a wide range of concepts. Unsatisfied with the existing methodology, the abovementioned philosophers investigated the direction opposite to the positivism tradition. The platform of Lebensphilosophie was elaborated by many works mutually enriching each other. F. Nietzsche and H. Bergson's ideas were crucial for the school because they reconsidered many concepts of the existing philosophy. With time the new approaches of Philosophy of Life were interpreted broader and deeper by E. Husserl and others.

The works of philosophers show that they clearly have made their attempts to overcome the methodological crisis faced at that time. They believed that the crisis was caused mainly by positivism and materialism concepts. The philosophers were against the lopsided and limited positivism approach; they looked for a new key notion capable to crystalize their vision of Life and Universe. The notion of Life became the core category of their philosophy and shaped the worldview of the school. Various interpretations of the notion of Life were developed within the school itself and out of it. Life, Individual, the role of Arts in cognition of Verity and World were reconsidered by Lebensphilosophie aimed at revealing principally new approaches to them. Such notions as Elan Vital (Vital Impetus) by H. Bergson and the Life World by E. Husserl were introduced.

These philosophers refused to accept ideas of the previous philosophical schools, the latter had been detached from an individual because the subject and object of their studies were Abstract Life and Abstract Human Being. The cognitive ability of a human intellect, as the only most powerful tool, had been under their critical reconsideration too. The founders of Lebensphilosophie asserted that the objective reality cannot be explicated by narrowminded abstract categories. This was the reason why the notion of Life became the starting point of their philosophic studies and special attention was paid to Life as a whole that could be understood only from within.

The notion of Life seemed to be the closest to the discourse of world and individual. There were not many philosophic schools where the core notion had such a diverse and rich semantics, fluidity and challenge for interpretation. Life was interpreted in terms of biology by L. Klages, in terms of cosmology by Bergson and Nietzsche, in terms of history and civilization by W. Diltey, H. Simmel and O. Spengler. 
Historically the western philosophy considered Life as an abstract objective category but Lebensphilosophie filled Life with an inherent component beyond rational and/or scientific contemplation. This way the philosophers replaced the canonical objective reality, as the foundation of everything existing in Universe, with Life in its permanent progression and genesis. According to the representatives of Lebensphilosophie without Life there was only the dark kingdom of nothingness. However, the philosophy of life did not reject presence of the objective reality, the Nature, that was detached from an individual. The same time that objective reality was dead without axiological categories. The philosophers focused their attention on the component of Life that could not be comprehended by ratio -- the scientific and logical tools only.

The philosophy of Life suggested a complex interpretation of Life instead of the generalized discourse of the objective reality where life had a narrow mundane meaning and was a purely theoretical element of an objective reality. Their interpretation broadened the cognition boundaries of the phenomenon and re-introduced Life as a permanently evolving genuine and primary reality in its entirety.

According to H. Rickert, Life should be placed into the center of the world and everything interpreted by philosophy should be in correspondence with Life. Life is the key to all doors of the Philosophy building. Life is the subject of the world, the same time it is a tool to cognate it. Life should be interpreted from within itself without other notions and such philosophy should be directly experienced [4].

H. Bergson in his Creative Evolution declares that Life is the object and primary reality. He interprets it as a universal evolutional principle of everything that comes to reality, grows and dies off in due compliance with its cycle. F. Nietzsche writes that Life is a part of the universal process, a specific kind and representation of the cosmic energy [5]. Life is neither a mere biological process, nor it is just a rational function of a human intellect but a complex phenomenon. The Universe seen through the prism of Life is spiritual and alive. Works of philosophers of this school convey a conviction that Life is more real than the objective reality and should always be studied in close connection with an individual. Correspondingly, the gnostic categories of the subject and object have been transformed and they are no longer considered abstract and self-contained by representatives of Lebensphilosophie. In his Introduction to the Human Science (1883) W. Diltey writes about a need to accept as a basis for study an individual in his richness of desires, emotions, interests, in other words to study life as a whole.

Lebensphilosophie brought Life in its entirety, as the primary reality and the process of nature, back to philosophy of the times when Life had not been split into its material and spiritual components, into form and mind yet. Life is a reference principle presented as a self-sufficient basis for objective reality, as the sovereign power creating a living form, and the Will to Live is the driving impulse for Life to start. This postulate is crucial for Nietzsche's philosophy. Life is an axis and all ideas of Thus Spoke Zarathustra (1883-84) rotate around it. In this allegoric poem the author manages to convey the novelty of mental outlook of the philosophical movement. The idea of Life associated with the Will to Power is correspondent with life in general. The Will to Power is more than a notion, it is a complex polysemantic category denoting everything that has energy to expand, i.e. to apply its power. This is the basis for evolution of the world. Life has an inherent tendency to expand. An individual and the world are inseparable, an individual existence and the objective reality make the whole that cannot be disintegrated into matter and spirit, object and subject.

Life is interpreted by F. Nietzsche as synthesis of the Dionysian origin with its joyful and instinctive assertion of thirst for life and the Apollonian origin that is the spiritual one. The Dionysian origin stands for artistic forces bursting through the nature and creating a human being. The image of Zarathustra that fascinated many minds at the turn of XX century was the allegory of the Will to Power. "F. Nietzsche never questions Life. Life is never wrong. To justify its existence everything needs to partake and be linked with Life. Life, for Nietzsche, is an immanent diety, the objective reality itself that is active, inconceivable, and unconditionally superior over any conceptualization and comprehension. Life fights, expands, grows, risks, flourishes and dies. Life always strives for expansion and selffulfillment, for increase of its might and power" [6]. F. Nietzsche imagines Life as an inextirpable force, the unbound energy of elements that gives birth to the diverse entities; they all are alive and spiritual. Vizgin argues that the multidimensional notion of Life has been narrowed by Nietzsche while rejecting the transcendental dimension of Life. The latter shrinks to the cataphatic biological notion without its apophatic description and antinomy. The artificial and lifeless dichotomy (Life is atheistic, God is dead) was put into the foundation of Nietzsche's philosophy distorting the mental structure but facilitating the reasoning process [6]. F. Nietzshe links the concept of Life with two notions: the Making of Life and the Might of Life. The Making of Life is intrinsic with the Might of Life thus with Virtue and Self-Dependence; being endued with virtue implies the high level of vitality and, subsequently, of civility, fairness and strength. The concept of Nietzschean life is infused with the value of life.

H. Bergson's interpretation of Life is multilayered as well: Life is linked with creative evolution and elane vital (the vital impetus). In his Creative Evolution published in 1907 Life is described as the universal power with the unlimited creative impulse. The most critical feature of Life is its ability to evolve. Life is enigmatic, and it is the source of the universal spirituality. Life is compared with impulsion because it is impossible to find anything else in the physical world close to the image of Life. A researcher wrote that H. Bergson's approach to the world was qualitative compared to, say, scientific approaches that were quantitative [7]. Life is in perpetual motion compared to the static objective reality which has dominated the western philosophy for centuries. "Bergson places an individual to the center of nature, to the center of Life. An individual is in interaction with everything around him and thanks to the interaction he grows and equates with Nature. Everything alive holds on to each other and they all are moved by the same mighty current" [7].

Following F. Nietzsche and H Bergson's interpretations of Life, W. Diltey studies Life as a stream of socially and historically determined emotional experience of an individual. Complex, controversial and multifaceted notion of Life is detailed as an enigmatic stream of obvious and hidden, distinct and vague. Life is compared with Sphinx, Life can be grasped from within, i.e. through personal experience only. For W. Diltey, life is mostly the spiritual psychic activity of an individual who creates his own world. The objective reality does not exist out of the subject. We are not aware of the real world if it is out of our conscience, we are aware of the reality due to our will and definition of the objective reality while our impulses face resistance.

The psychological interpretation of life is an obvious undercurrent of Diltey's notion of Life. He had in mind not only the empirical multiplicity of individual lives but some spiritual bonds uniting the lives of currently living people with those of the past and future [5]. The father of hermeneutics interpreted life as the direct emotional experience. Life is always the life of an individual according to W. Diltey.

The above described re-invention of Life by Lebensphilosophie dramatically expressed itself in Russian Arts and, specifically, in Russian literature at the turn of XX century. The ideas of Lebensphilosophie seamlessly blended with the intellectual life of Russian society and broadened the ontological horizons of the belle-lettre of that period. Lebensphilosophie pointed out that life is immensely richer than our rational picture of it. It did not matter whether the novelists of that period were familiar with the philosophers or not (for example, M. Prishvin's student years at the Leipzig University (1900-1902) coincided with the time when H. Simmel was Professor for the Department of Philosophy there), the air was heavy with the Lebensphilosophie ideas and the latter were easily disseminated within the cultural context of the period. In Russia the interest in works by F. Nietzsche, H. Bergson and others was huge. The first Russian publication of Thus Spoke Zarathustra was in 1898, The Birth of Tragedy from the Spirit of Music in 1899, the eight-volume collection of F. Nietzsche's works was published in 1900 and its second edition took place in 1902/03. H. Bergson's Creative Evolution was published in Russian in 1909 and the collection of his works in five volumes was published in 1913-1914. Russian periodicals Russkoe 
Bogatstvo (Russian Wealth), Russkaya Mysl (Russian Thought), Severnye Zapiski (Nothern Notes) regularly published European philosophers and representatives of aesthetic movements. They were popular in Russia as well. Good command of the leading western-European languages among the Russian intelligentsia was another reason for their direct access to the most recent foreign publications.

Lebenphilosophie ideas were disseminated not only by original works, their reviews and digests in journals but also by corresponding critic publications: F. Nietzsche: Critic of Altruistic Moral by V. Preobrazhenskiy in 1892, Modern philosophy in Germany by 0. Kulpe in 1902, Introduction to the Transcendental Philosophy by H. Rickert in 1904, On Liberty by J.Mill in 1906, Philosophy in Systematic Rendering by W. Diltey, A. Riehl, W.Oswald and others was published in 1909, Intuitive Philosophy of Bergson by N. Lossky, F. Nietzshe in the Light of Christian Worldview by I. Slobodsky. These articles and books interpreted specific points of the ideas, disputed them and in their own way added to the increasing rejection of the positivism ideas. Gradually, this tendency transformed all spheres of the Russian intellectual life and, most of all, the Arts.

\subsection{Concept of Life in Russian Literature Neorealism and Belle- Lettre}

The Nietzschean philosophy significantly influenced the self-awareness of the Russian society during that time. Artists of the younger generation were interested in various aspects of his philosophy. Theoretical studies of classical arts by Nietzsche were interesting for D. Merezhkovsky, Vyacheslav I. Ivanov. The aesthetic ideas of his philosophy were appealing to others. Thus Spoke Zarathustra was the best-seller of the time and the idea of the Overman resonated far and deep thanks to the rebellion spirit and individualism that could not be limited by an ordinary desire of a freedom-seeking person to push the ethic limits of the society. Reticence, ambiguity left room for imagination and significantly influenced artistic concepts of the Russian modernism. We find similar themes, interpretation of images, discussions of philosophic ideas in works by N. Minsky, Z. Hippius, A. Block. N. Gumilev, V. Mayakovsky, etc. The footprint of the scope and diversity of Nietzschean ideas on the artistic conscience of the Silver Age allows to speak about their complex effect on the Russian Literature at the turn of XX century $[8,9]$.

The Russian Literature neorealism was on the sideroad of Nietzsche's influence compared to the Russian symbolism which focused on his ideas of eternal recurrence, the Overman, cultural attitude. The idea of life in Russian neorealism lead to forming the worldview with new values and changed the axiological colors of the way Life and Individual were perceived. The Russian Literature neorealism became a specific reaction against the theories of positivism that dominated over the Narodism literature of $1880-90^{\text {th }}$. The ideas of Lebensphilosophie specified the trajectory for new realism at the turn of XX century. Under the influence of this school the Russian literature abandoned its positivistic approach towards life as well as the ideas of social detrminism. This rather narrow interpretation of life was typical for the democratic belle-lettre of 1860th and continued to be used by such authors as N. Zlatovratsky, N. Timkovsky, F.Nefedov, P. Zasodimsky, S. Gusev-Orenburgsky, N. Teleshov, etc in 1880-90th.

The Narodism literature rigidly tied an individual with his/her social environment missing complex bonds with the world at the expense of social factors. The weakness of Narodism literature was caused by the fact that it limited itself to the social issues of everyday life. It kept accumulating 'cases' but did not philosophically contemplate them, consequentially this kind of fictional prose gradually relegated to the back burner. The ideological constants of Narodism as well as the repetitive plot of a weariful, stagnant, deeply unsatisfactory daily life under heavy pressure of social constraints brought the Russian Literature of $1860^{\text {th }}$ to depletion. The literature of 1880-90 maintained raw description of daily routine of peasants, villdom families and self-employed plebeians but for readers it was felt outdated. The rationalistic picture of the world, rendered futile and reduced to its basics, turned out to be fruitless and distorted.
Aesthetic expressions of the Russian Literature neorealism were different from traditions of neonaturalism (M. Artzybashev, I. Potapenko, P. Boborykin, etc.). Neonaturalism came to rise due to the new postclassic paradigm of thought in different areas of natural science and fine arts. New biologism, the principle of accurate research, attention to details and a wide variety of daily life became the methodological foundation for neonaturalism. Artistic description of the objective reality was replaced by an empirical description. This trend in Literature imitating "truth", "veracity" focused on description of a human physiology and made biological determinism its corner-stone.

Both, the neoNarodism and neoNaturalism prose, were fringe movements of the Russian literature of $1880-1890^{\text {th }}$. In its pursuit for fresh ideas to reflect life adequately and fully, Russian realism found Lebenphilosophie at the turn of the XX century. The accents got shifted, the values were reconsidered. Works of that period witnessed a persistent search for positive values beyond "circumstances" and a focus on eternal issues like pantheistic feeling for cosmos, nature, love, arts. A certain philosophical program was followed: endorsement of life for the sake of life, the idea of sacred life, its inherent worth regardless to any social evaluation. Fulfilled and bright life bringing satisfaction was opposite to the Narodism philosophy that rejected benefits for the sake of abstract mission to serve social goals while ignoring life itself. The Russian Literature neorealism was flesh and blood of the attitude brought to the Russian soil by Lebenphilosophie.

Under the influence of Lebenphilosophie, the Russian Literature upgrades itself to a new level: it becomes more spiritual while interpreting life, focuses more on the meaning and multidimensionality of life. It is characterized by naturalness, spiritual might and glory, entirety of emotions. It celebrates the poetic vitality of life together with Lebenphilosophie. Feelings are more intense. In the Russian Literature neorealism, the concept of objective reality is constructed on the awareness of complexity, fluidity, eternity of the world, on the idea of bonds of each and every phenomenon with the entire and infinite world.

The ideas of Lebenphilosophie gave rise to other philosophic movements of the XX century, in particular, to Existentialism that has a different attitude to Life. Z. Hinadi notes that "Lebenphilosophie, compared to Existentialism, has an optimistic collective character of the strong ethos and does not have personalized individualism" [10].

The critical thought of early XX century, based on Nietzschean ideas, calls to resurrect the sense of life, healthy instincts. In his Meaning of Life R. Ivanov-Razumnik writes that the actually ultimate message of the Russian Literature neorealism is that" The goal of life is not happiness, not pleasures but its abundance. Let the body suffer if the soul is ecstatic. ...if the subjective goal of life is fulfilled, if sufferings of body and soul enlighten an individual to see the depth, scale and intensity of his existence. Fulfilled life is the utmost justification for the individual's existence" [11]. The aesthetic category of Living Life comes to rise in V. Veresayev's works Living Life and Apollos and Dionysus (About Nietzsche). The idea is also artistically implemented in his short novel Towards Life. Critics agree that $V$. Veresayev evaluates the Nietzsche's idea of the Overman from the point of view of his Living Life theory. V. Veresayev interprets the Overman concept as a plea to resurrect the sense of life, healthy instincts, and as a desperate longing for better times for the mankind. The same time $\mathrm{V}$. Veresayev underlines that the Triumph of Instincts is substituted by the Will to Power. V. Veresayev agrees with F. Nietzsche that Life is a mix of Apollonian joy and Dionysian suffering; the Dionysian wine symbolizing artistic or religious ecstasy is an inherent and critical component of living life. The same time he argues that Dionysus headship is wrong as is his confidence that wine is the only means and justification for life, the only remedy to overcome hardships [12]. For V. Veresayev, Apollos and Dionysus are not antipodes but two sides of Living Life. Except some details, the interpretation of Living Life by V. Veresayev and the Lebenphilosophie's concept of Life are close to each other.

At the turn of the century the positivism ideas were rejected not only by realism that was undergoing transformations but by Fine Arts in general. "Wholeness of Life" was not considered as Wholeness of social life any 
longer. In the XIX century literature Life was viewed as stable but, in the beginning of the XXth century literature, as a component of the nonstable equilibrium (V. Rosanov). Early XX century scientific findings (Einstein's theory of relativity, the idea to overcome gravity, to divide atom) were impressive and could not but change the picture of the world and add another meaning to evolution of life.

The ideas of Philosophy of life had a far-going influence on I. Bunin, B. Zaitsev, M. Prishvin, S. Sergeyev-Zensky, I. Shmelev. An absolutely new approach to an individual, his existence and his spot in nature correlates very well with the worldview of representatives of Lebenphilosophie in works of these writers. The philosophic ideas influenced the Russian literature neorealism mostly through their focus on the essence of a human life. At the turn of centuries, evolution of social, psychological and aesthetic ideas prepared Literature to accept Lebenphilosophie as if it had been born from within the literature. V.A. Keldysh, underlying the general non-positivistic character of literature of that period, writes that transformation of the public conscience touched mostly the relationships between an individual and his/her social environment [13].

The works of Russian neorealists are saturated with the sense of beautiful and tragic world, its permanent decay and renaissance. Mortal life is a flash against the majestic background of the eternal Universe. In the Russian literature neorealism, the categories of time reveal the correlation between the temporary period of a human life and the time of Universe. Diverse manifestations of the objective reality are not self-contained. For the writers the world is unblocked, everything is along the same row, merging with each other. The ability and intensity of life as the whole to express itself through nuances of interactions and interrelations with the world is a new experience for the Russian literature.

Awareness of the endless variety of life, its infinity and pulsation is obvious in I. Bunin's works (Antonov Apples, From the Heights, Pine Trees, Silence, In the Beginning, Fog, Dreams, The Golden Bottom, etc.), B. Zaitsev's works (Myth, Colonel Rosov, Priest Rosov, The Young People, etc.), M. Prishvin's works (In the Land of Unfrightened Birds, Bun, etc.), I. Shmelev (Grapes, GoRound, Rosstani, etc.), S. Sergeyev-Zensky's (Motions).

The characters of their stories experience joy of union with nature, reflect on the mystery of birth and death, the true meaning of their environment. The stories are saturated with the sense of coherence with the world. It comes through profound immersion into life as a whole and an inseparable stream of life in the world and in an individual.

\subsection{World's Beauty In Philosophical Miniatures}

In philosophical miniatures full of lyrics, I. Bunin expressed intense emotions of the widest range - from passionate ecstasy to depression and melancholy caused by loneliness of an individual and fragility of life (Tanhka, Kastryuk, Melython, Pine Trees, Epitaph, etc.) written in 1900 $0^{\text {th }}$. The symbolic images of tranquility, a mountain pass or dawn convey not only the author's mood but also reflect his new attitude to the world, his profound penetration into the human nature. Beauty of the world and its sensual perception are artistically depicted. For example, his miniature Silence (Tishina)is about the perpetual process of life and its repetitive resurrection. It is about an individual merging with nature around him that becomes an inexhaustible source of strength and creativity. The story is about the Geneva Lake and valleys of the Savoy mountains. The characters are stunned with the majestic rocks and the brilliantly clear lake. In a serene late autumn day, the chime of remote bells brings back fond memories about Cologne Cathedral and its medieval organ. Beauty of nature brings the desire to rise up to it. Sensation is so strong, life is so fulfilled that the little bell tower glorifies peace and silence of Sunday morning for the main character $(2,239)$.

I. Bunin's oeuvres of the $1900-1910^{\text {th }}$ reflect the artistic tendencies of the period. His stories are characterized by philosophic analysis, interest to the elements of existence, thoughts about dark pre-dawn chaos. He is trying to comprehend a place of an individual in Universe. I. Bunin's works brightly reflect $\mathrm{H}$. Bergson's idea about the truly individual conscience as the reflection of the deepest level of human spirituality. The author takes the inward turn in his stories and confesses with the moving emotional lyrism about the stream of life and time, filling it with very personal, almost intimate, content. These features are agreed to be typical for Bunin. Psychological analysis, details of sincerest confessions of characters, spiritual contemplation of the inner and outer worlds are the features of Bunin's enriched realistic style. It is not limited to the pioneering technique of storytelling but reveals a new attitude towards the world and an individual.

Compared to modernism, the Russian literature neorealism has not accepted the idea of a strong personality. Nietzschean Zarathustra with his will to power, vitality, self-esteem becomes a prototype for many modernism artists. Another facet of Nietzsche's philosophy - the vigorous and fulfilled life-is more appealing to the Russian Literature neorealism. His idea of Beauty does not go unnoticed. In his collection of aphorisms Human, All Too Human: A Book of Free Spirits (1878) he writes that through millennia Arts teaches us to accept life with curiosity and joy in any of its forms and to refine our senses up to the point we can exclaim "Life is good no matter how it is going on, Life is good [14]. F. Nietzsche cites Goethe and sets the crucial goal for Arts to educate people to enjoy their lives and considers a human life as a part of nature [14]. This thought is intensely elaborated by writers of the Russian neorealism movement.

A set of sketches written by B. Zaitsev about his journeys to Italy (190720) are saturated with philosophic issues. This example of travel literature stands out due to the vibrant feeling of life's diversity and the artistic expression of infinite possibilities with which life may express itself. His reverential attitude towards Italy and his almost obsessive desire to visit the country is obvious through his correspondence and memoirs; not surprisingly, the set of sketches graphically narrates his four trips to Italy. The Italian set by B.Zaitsev is about the philosophic and aesthetic perception of the country, as well as its history and culture, which have special significance in the context of the author's philosophic views and the Russian Literature neorealism. The author felt at home in Italy and identified with it as he did his native country. The topics of the sketches are united by the same theme because of author's exposure to the Italian culture. The special artistic world of B. Zaitsev was acclaimed owing to the idea of beauty that is in itself the aesthetic quest of the artist. In the sketches about splendid Italian cities - Venice, Florence, Rome, Genoa, Fiesole, Pisa, Assisi - there is a strongly pronounced lyric component.

In Rome, a traveler senses the shadows of historical events. The classic style and forms of the epoch, as well as the artistic manner of craftsmen, convey the aura of that period for the author. He notices that forms and proportions of classic architecture had been well-thought-out and measured. He is amazed by the grandeur and noble forms of halls with domes, pillars and portals marked with the touch of high classics, elegant details, and plasticity of forms. The image of Rome is associated with a heroic symphony: majestic, enigmatic and melancholic. This impression comes from gazing at contours of the Forum, the splendor of medieval cathedrals, and the glory of St. Peter's Basilica that is an example of harmony and music in stone. Rome and the Vatican in particular, are majestic but reserved without Yang energy in it. Rome is formidable and tragic; it lacks ethereality, or any feeling of tenderness and charm that is sensed in Florence. Rome is saturated with traditional features of imperial stateliness and civilization. The author tours early Christian basilicas and visits ancient ruins in the city and its vicinity. In his eyes, ordinary buildings made of brick and stone embody the spirit of Rome through their harmonic proportions, chastity and classic style.

Tours to different Italian towns are more like pilgrimages to the sights embodying the Roman spirit rather than excursions of a typical tourist. He admires pieces of arts and captures their zeitgeist as they have not lost the energy of their creators. The Roman civilization was an incentive to the imagination of the artist prompting him to return to Italy repeatedly. In Italian sketches by B. Zaitsev, we read the hymn to Venice, shining in its glory and solemnity. While looking closely at the Venetian palaces and basilicas, the greenish waters of canals, the gondolas, and Ponte di Rialto, the author immensely enjoys the timeless paintings by Veronese and Titian, Giorgione and Tintoretto. He experiences the sense of beauty too deep for words. Whether in its architecture, monuments or landscape, 
vitality and abundant life is sensed in each page of this book about Italy. For him, St. Mark's Basilica looks like the epitome of Venice: ancient and alive. Everything is alive there - the cool and humid air, the fancy mosaic of the floors and the mysterious twilight of a huge rosette [15].

In the Italian set, the abundant life represents the spirited form of the experience of intense world beauty. Some spiritual work that started centuries ago is continued in another epoch with its uninterrupted emotions and thoughts. The image of Venice is that of perpetual festivities which conveys the feeling of abundant life, thus explaining the pomp and pageantry of famous Venetian carnivals. In addition to Zaitsev, may other Russian artists point to its wealth, luxury and refinement as a specific feature of the city. For example, Pavel Muratov wrote Images of Italy (Obrazy Italii) with similar affection. R. Gaman, an art critic of impressionism, underlined that Venice will always be the place where anticipation of pleasure comes to fruition. It is the city of refined aesthetics cultivating the emotions of life fulfilled [16].

One of the main messages of the Italian sketches is that of the inseparable bond between Life and Death. The best pages of the book are marked with reflections upon transience of life. For the artist the kiss of death is more present in Venice than in any other place. He writes "Nowhere is night's melancholy as dark as in Venice, nowhere is day's charm brighter than in Venice. Nowhere exists a more striking contrast between the golden strokes of Titian and the wave of chaos, between a vortex of youth's gaiety, the blaze of luxury and bubbly wine, a flirtation of smiles and tender strokes and the great silent midnight waters. Venice is two-faced, sharp piercing, gleefully mourning -- memento mori over the never-ending carnival of life [15].

The city that stirs thoughts of eternity is light-pink Florence - the city of everlasting beauty. Zaitsev is enchanted by the sophisticated simplicity of the city. He tries to grasp the secret of harmony between material and spiritual, mundane and sky-born created by human genius which is beyond the decay and bloody chaos of history. Delight and fascination are stirred by his direct viewing of paintings and monuments, windy streets, cozy or grand squares, chapels, towers, everything! He writes that he fell in love with Florence at first sight; he "recognized the birthplace of Souls". He compares Florence with the place that brings happiness and where dreams rejuvenate hearts [15].

The artistic image of Florence is like a rainbow of colors or like a musical instrument with many keys. The soul, immortal and beautiful, is exemplified by the energy of paintings by Botticelli, Raphael, Fra Angelico, Filippo Lippi, and the poetry by Francesco Petrarca and Dante, frescos by G. Cimabue and Masaccio. In its history, the city lived through triumph and death. While looking at the gothic arches and stained glasses of the Cathedral, B. Zaitsev keeps asking "Was Dante here?" The high ideals of Dante's oeuvre affected thoughts of the Russian writer about the spirited beauty of Florence. The sketch has the rhythm and elegance of the place "...decay has no power over this city because some undecayed idea got incarnated into it and carries on its life" writes Zaitsev about his feelings of Florence [15].

Any trip for an artist is not only about new discoveries of the location and its history, including its culture and people, but also about a way to search for his/her inner self. A focused look at relationships between Italians and their way of living in rural and urban areas evokes reflections of harmony, fine arts and the human spirit that created them. In his Italian sketches, B. Zaitsev continually highlights the inexhaustible wealth of beauty of the world that surrounds us. His personal evaluation system, free of ontological and metaphysical conflicts, gives the highest praise to the quality of subliminal aesthetic emotions. Thanks to his personal experience of objective reality, he extensively broadens his subjective world by poetically connecting his inner self with the distant past, which was another civilization [17]. The artist accepts life in its entirety as a category that is in the process of its perpetual evolution.

The moral principles of arts are the keynote of Zaitsev's Italian set. Genoa is the embodiment of a proactive approach to life -- its energy, passion, and colors are of the bright sunny spectrum. Rome and Florence leave an impression of culture as tradition and a spiritual hub, but Genoa leaves that of the "taste" of the pompous merchant, such as mismatched buildings, and a rough and tricky business beat. It is a port city that could not care less for fine arts and philosophy, because life here is dictated by trade. The energy of the city founders set the tone for the original inner tension of the place. It is vibrant, loud and triumphant. The spirit of Italy is here. However, it is another Italy. Zaitsev defines it as the Italy of Aphrodite Pandemos. B. Zaitsev writes, "The ships entered the port of Genoa with textiles, indigo, and silver, rather than with manuscripts of ancient Hellas". Gaucherie of the locals is inseparable from the hard labor that brought the city into existence. While in perpetual motion of its business activity, the city keeps evolving and leaves room for its cultural maturing.

B. Zaitsev's mental pictures of Italy are the expression of the ideal human life, fulfilled on the mundane level. The Italians profess their love and zest for life in their daily activities by introducing joy into everything around them. The artist affectionately describes how easily the Italians are agitated, how hard they work and how eager they are for leisure. The down to earth rural life is in contrast with Roman greatness and the Venetians opulent way of living. At the same time, it provides the cultural background that ensures the healthy moral foundation of the ordinary people. The aesthetic sensitivity of the nation is due to the inherent harmony of their inner world with the outer, whether it is nature or urban environment. It has not been lost in the centuries separating the masters of the past from the modern population.

The book about Italy conveys not only his impressions of the architecture, the arts and the Italians, but the set of sketches brings forth the emotions of timeless reality which is objective though unperceivable. B. Zaitsev fixed in a limited textual space the complex polyphonic and multilayered feeling of "his Italy". This new feeling is light and translucent, as though painted in water colors. It enriched his prose of $1900^{\text {th }}$ with new denotations.

\subsection{Shmelev \& B. Zaitsev: Bergsonian Perspective}

The abundant life - diverse, immense, inexhaustible--has different ways of expression in the Russian Literature neorealism. I. Shmelev is surprisingly sensitive to the subtlest shades of life. He masterly creates an ornamental picture of life paying attention to the density of material world, its tangibility. The reality feels pulpable in his works of $1900^{\text {th }}$. 'A poem about triumphant life in prose' call literary critics his story about the alchemy of Spring Wind [Vesenny Shum] (1913). The keynote is the circle of life with repetitive rejuvenation. The plot is about a frustrated young man returning home after being kicked out of a divinity school. He is crossing a field. Deep remorse, aching void, sickening fash are all mixed into one heart-burning feeling. It is one of the earliest spring days: gray low skies, not awaken ground, water with icicles, rustle of leafless woods. The artist describes nature just before it awakens. No detail is left unnoticed. The significance and sonority of the event is highlighted. The story ends with the psychological resolution of the plot: the young man is enchanted by nature. His mood slowly transforms, a mixed feeling of loneliness is gradually improved by a desire for some happiness; the nature increasingly uplifts his mood bringing him back to life. The philosophic reflection is the following: "Vasya was walking back home, sun was in zenith and the noise of rooks was getting louder at this time of day. He was thinking that there was many a different path in the fields which were wakening up each spring, in a sure return of migrating birds, in green leaves that never fail to come" [18].

In Russia of early $1900^{\text {th }}$ Bergson's philosophy of Intuitionism reached its peak stirring debates in intelligentsia circles. The aesthetic part of it touches the issues of an artist in this world, the essence of creative activity and the role of intuition in it [19-21]. The gist of Bergson's concept is about reforming arts by incorporating human experience directly into arts. Bergson dismantles philosophic stereotypes of the previous centuries which, as he believed, are too focused on epistemology and the theories about truth but not enough on truth itself. Time and Free Will: An Essay on the Immediate Data of Consciousness (1889) and Evolution of Creativity (1907) are about failure of science and philosophy to find Truth. He contrasts the rational approach with intuition as a way of finding truth, 
especially in creative activities because intuition allows to capture the essence of objective reality in its entirety and in its living state. The science studies the objective reality by purely logic techniques. The goal of arts is to reveal the subjective reality that is not on the surface. Bergson calls it "the other knowledge" or "the other half of the reality where intellect merges with intuition" [21].

Duration of time is the foundation of Bergson's philosophy. Duration is understood as a psychological subjective concept of time. It cannot be confused with immobile (linear) time used by science. Introspection, according to H. Bergson, reveals that life of conscience, in other words the internal life of an individual, represents a chain of mobile states gradually transforming into one another, i.e. it is under continuous duration. Duration can be grasped by intuition.

Each of us has individual and social representations. Individual representation is our inner self and we can grasp the objective reality in its entirety by immersing into our individual representation. Our social representation is a pale outward projection of the individual representation. Bergson argues that the subjective perception of the world rectified from its empirical content provides us with an efficient methodology to study the world. The philosophy of intuitivism resonated well with the aesthetic stance of impressionism, symbolism, existentialism, surrealism and other artistic trends. The Russian Literature neorealism is focused on the inner representation of an individual. It is the reason why instead of the three-dimensional character, we read about certain facets of a character, like sorrows, joys, sufferings.

The Russian neorealism writers pay more attention to the inner world of their characters, shades and nuances of their psychological state and describe nature through emotions. The reality - the foundation of the realistic technique-is reflected through the prism of soul. The ideas of H. Bergson are fruitful for them. The writers devote a bigger role to the emotions and feelings caused by the reality, for example, I. Bunin in his stories At the Beginning, From the Heights, Fog, Silence, Campfire, Autumn; B. Zaitsev's Night Dream, Quiet Dawns, Tranquility, Sister, Blue Star; M. Prishvin's Adam and Eve, Black Arab, or S. Sergeyev-Zennsky's Motions. Their landscape descriptions sound like paintings in words - the reader recognizes impressionism techniques seamlessly combining air and light with added touches of colors. This approach is typical for early Bunin's prose. B Zaitsev, compared to I. Shmelev, ignores the material density but prefers rhythm and melodic accents. Following the impressionist style, the writer combines subtle shades of colors presenting amazingly multilayered world.

In the Russian literature neorealism, the impressionism tendencies display themselves in a few new ways:

The writers depart from the epic narrative scale in depicting the outer world. They become better aware that the big world is reflected through the smaller world. The subjective worldview and the elements of lyrism start prevailing over the big scale descriptions that have been considered a must feature of the XIX century realism.

The writers prefer the composition of fragments over a lined-up structure of the plot. Naturally, it influences the way the plot is perceived. A fact turns to a starting point for a flood of emotions and neither a full-dressed plot, nor the concluded ending are an inherent part of their oeuvres any more.

Impressionism also increased the popularity of the genre of short stories, essays, written outlines, poems in prose, philosophic miniatures. I Bunin, B. Zaitsev and I. Shmelev are masters of small literature forms.

The boundaries between genres became flexible and got diffused giving rise to new modifications and specifying the processes that took place in literature and genres system of Russian neorealism at the turn of the XX century.

\section{CONCLUSIONS}

In the beginning of the XX century Lebensphilosophie (W. Diltey, F. Nietzsche, H. Rickert, O. Spengler, G. Simmel, etc.) and Intuitionism (H. Bergson) ideas significantly influenced the Russian Literature and formed a different picture of the world giving rise to new approaches for interpreting the objective reality and an individual. The influence of these philosophic movements was immensely fruitful for forming the new trends in Russian literature. According to the philosophers, Life is an entity that cannot be split into matter and spirit, object and subject thus an individual and the world are inherently united.

The literary practice of Russian neorealism did not accept all ideas of the philosophic movements. Quite a few popular ideas of Nietzschean philosophy were ignored, for example, the ideas of eternal recurrence, the Overman, the concept of culturology. The second thought was given to the established values that were widely interpreted in symbolism and impressionism but not in literary neorealism though they left their light footprint there. The Russian literature eagerly embraced the ideas that life is valuable, and the objective reality is vital. Regardless to the parallel presence of attractive modernism tendencies in literature, the phenomenon of neorealism did not get lost or dissolved in them but digested and expanded the neorealism space. The artistic picture of the world of the Russian literature neorealism was constructed on the pillars of synthetic concepts of about life and Universe of Lebenphilosophie and Intuitionism. The aesthetic traditions of these philosophic schools of thought bring us closer to comprehension of the literature neorealism phenomenon in Russia, if not in its entirety, then, at least, a rather full picture of it.

\section{ACKNOWLEDGMENTS}

Research was funded with grant AP05136097 of Ministry of Education and Science, Republic of Kazakhstan.

\section{REFERENCES}

[1] Katayev, V.B. 2001. Realizm i naturalism. In V.A. Keldysh, ed., Russkaya literatura rubezha vekov (1890- nachalo 1920-kh godov. [Realism and Naturalism, Russian Literature Abroad (1890 through $1920^{\text {th }}$. Book 1. Moscow: Legacy [Naslediye], 193-215.

[2] Kolobayeva, L.A. 2000. Russkii simvolizm [Russian Symbolism]. Moscow: Moscow State University Publishing House.

[3] Keldysh, V.A. 2001. Realizm i neorealizm [Realism and Neorealism]. In V.A. Keldysh, ed., Russian Literature Abroad (1890 through $1920^{\text {th }}$, Book 1. Moscow: Legacy [Naslediye], 259-335.

[4] Rickert, H. 1922. Filosofiya zhizni. Izlozhenie i kritika modnykh techenii filosofii nashego vremeni [Philosophy of Life. Summary and Critic of Contemporary Philosophic Movements]. Peterburg: Academia.

[5] Rumayntseva, T.G. 2002a. Diltey. In World Encyclopedia Philosophy. XX Century. Moscow: AST; Minsk: Kharvest, Modern-Day Writer, 236.

[6] Vizgin, V.P. 2000. Zhizn' kak tsennost': opyt Nitsshe. In Zhizn' kak tsennost' [Life as Value: Nietzsche's Experience], Moscow: Institut filosofii RAN [Institute of Philosophy RAS], 7-30.

[7] Grandjean, F. 1913. Revolyutsiya v filosofii. Uchenie Anri Bergsona [Revolution in Philosophy. H. Bergson's Concept]. Moscow: A. Levenson's fast print house. (In Russ.).

[8] Danilevsky, R. 1991. Russkii obraz F.Nitsshe (Predystoriya i nachalo formirovaniya), Na rubezhe XIX i XX vekov [Russian Image of F.Nietzsche (Early Years and Track Record and Formation)]. In Yu.D. Levin, red. Russkaya literatura rubezha vekov (1890-e - nachalo 1920-kh godov [Turn of XX century. From the history of International relations of Russian literature]. Leningrad: Nauka, 5-43.

[9] Danilevsky, R., Yu. 1998. K istorii vospriyatiya F. Nitsshe v Rossii [Evolution of Perception of F. Nietzsche in Russia], Russkaya literatura = [Russian Literature] (4), 232-239. 
[10] Hinady, Z. 1995. Russkaya filosofiya zhizni [Russian Philisophy of Life], Slavica, 25, Debrecen, 103-107. (In Russ.).

[11] Ivanov-Razumnik, R. 1910. 0 smysle zhizni: F. Sologub, L. Andreev, L. Shestov [Meaning of Life: F. Sologub, L. Andreyev, L. Shestov], St. Petersburg, $2^{\text {th }}$ ed., Stasulevich Publishing House [Izdatel'skiy dom Stasyulevicha].

[12] Foht-Babushkin, Yu.U. 2001. Vikentii Veresaev [Vikenty Veresayev]. In In V.A. Keldysh, ed., Russkaya literatura rubezha vekov (1890-e - nachalo 1920-kh godov [Russian Literature at Turn of Centuries (1890-through $1920^{\text {th }}$, book 1. Moscow: Legacy [Naslediye], 626-650.

[13] Keldysh, V.A. 1975. Realizm nachala XX veka [Realism at the beginning of XX century]. Moscow: The Science Publishing House [Nauka].

[14] Nietzsche, F. 1990. Sochineniya v 2-kh tomakh [Collection of Works in 2 volumes]. Moscow: Mysl Publishing House.

[15] Zaitsev, B. 1999. Sobranie sochinenii $\mathrm{v} 2 \mathrm{kh}$ tomakh, (6-7 toma dopolnit), tom 3. Zvezda nad Bulon'yu [Collection of Works in 3 (5), Star over Boulogne], Moscow: Russian Book [Russkaya kniga].
[16] Gaman, R. 1935. Impressionizm v iskusstve i zhizni [Impressionism in art and life]. Moscow: Association of Book and Journal Publishers [OGIZ]. (In Russ.).

[17] Romanovich, A. 1999. Italiya v zhizni i tvorchestve B.K. Zaitseva [Italy in Zaitsev's Life and Works], Russkaya literatura $=$ [Russian Literature $], 4$, 55-67.

[18] Shmelev, I. 1966. Povesti i rasskazy [Novels and Stories], Moscow: Fiction [Khudozhestvennaya Literatura].

[19] Koltonovskaya, E. 1910. Novaya zhizn' [New Life]. St. Peterburg: Public benefit [Obshchestvennaya pol'za].

[20] Koltonovskaya, E. 1912. Kriticheskiye etyudy [Critic Essays]. St. Peterburg: Self-education [Samoobrazovaniye].

[21] Rumayntseva, T.G. 2002b. Nitsshe [Nietzsche]. In Istoriya filosofii. Entsiklopediya [History of Philosophy. Encyclopedia]. Minsk: Intepresservice Publishing House, 715.

[22] Bergson, H. 2001. Tvorcheskaya evolyutsiya [Creative Evolution] Moscow: Terra-Book club). 